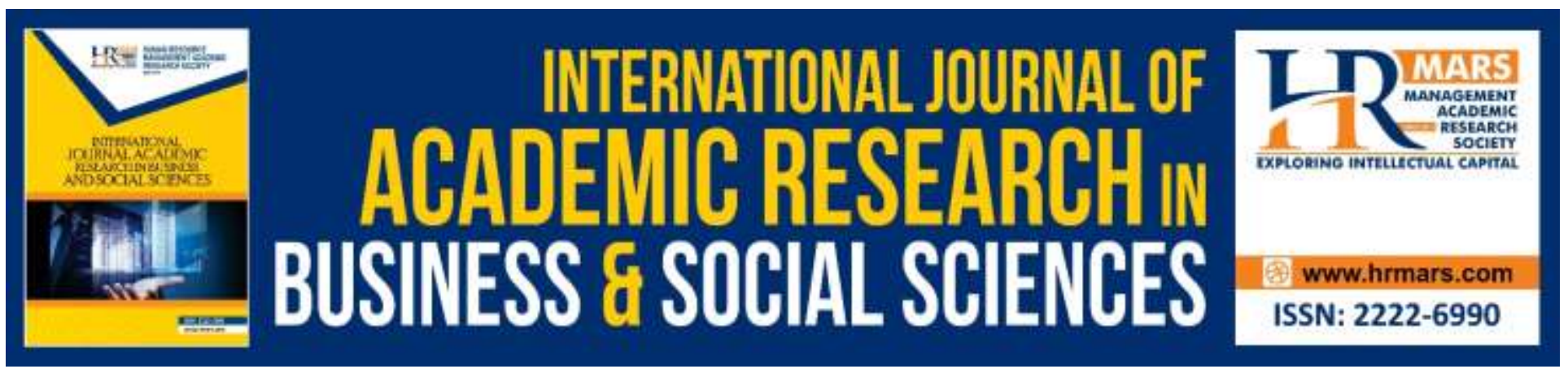

\title{
Social Media Addiction \& its Effect on Mental Health among the Private University Students in Bangladesh: A Questionnaire Based Survey
}

Tahiya Islam, Prokriti Wazed Sikder

To Link this Article: http://dx.doi.org/10.6007/IJARBSS/v10-i4/7129

DOI:10.6007/IJARBSS/v10-i4/7129

Received: 08 February 2020, Revised: 04 March 2020, Accepted: 25 March 2020

Published Online: 12 April 2020

In-Text Citation: (Islam \& Sikder, 2020)

To Cite this Article: Islam, T., \& Sikder, P. W. (2020). Social Media Addiction \& its Effect on Mental Health among the Private University Students in Bangladesh: A Questionnaire Based Survey. International Journal of Academic Research in Business and Social Sciences, 10(4), 281-294.

Copyright: (C) 2020 The Author(s)

Published by Human Resource Management Academic Research Society (www.hrmars.com)

This article is published under the Creative Commons Attribution (CC BY 4.0) license. Anyone may reproduce, distribute, translate and create derivative works of this article (for both commercial and non-commercial purposes), subject to full attribution to the original publication and authors. The full terms of this license may be seen at: http://creativecommons.org/licences/by/4.0/legalcode

Vol. 10, No. 4, 2020, Pg. 281 - 294

http://hrmars.com/index.php/pages/detail/IJARBSS

JOURNAL HOMEPAGE

Full Terms \& Conditions of access and use can be found at http://hrmars.com/index.php/pages/detail/publication-ethics 


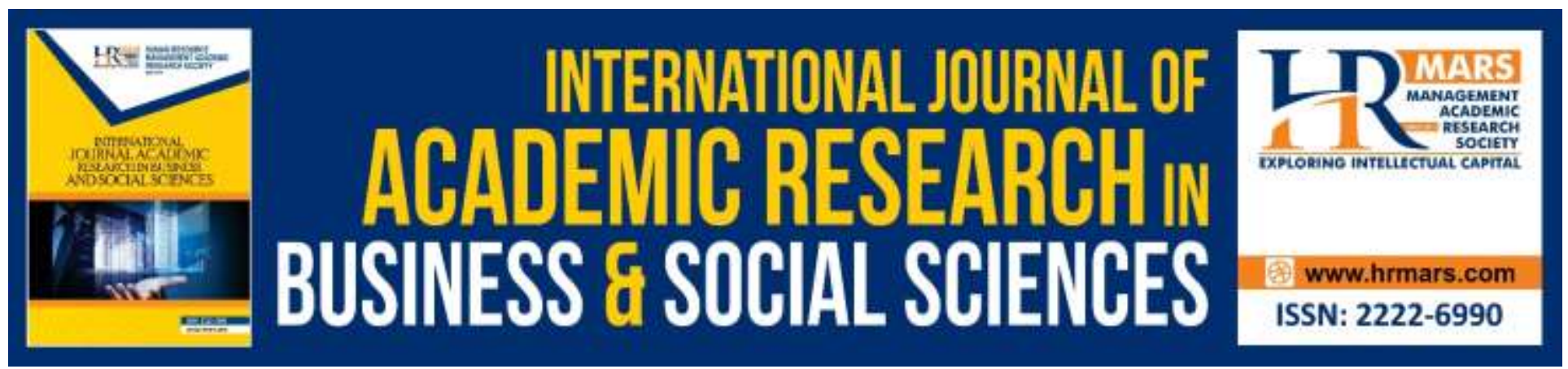

\title{
Social Media Addiction \& its Effect on Mental Health among the Private University Students in Bangladesh: A Questionnaire Based Survey
}

\author{
Tahiya Islam ${ }^{1}$, Prokriti Wazed Sikder ${ }^{2}$ \\ ${ }^{1}$ Department of Biomedical Sciences, Faculty of Medicine and Health Sciences, Universiti Putra \\ Malaysia, Serdang, 43400 Seri Kembangan, Selangor, 2 Department of Biotechnology, Faculty of \\ Biotechnology and Biomolecular Sciences, Universiti Putra Malaysia, Serdang, 43400 Seri \\ Kembangan, Selangor \\ Email: tahiya945@gmail.com
}

\begin{abstract}
In the 21st Century, the most practical and fastest way to reach information is undoubtedly the usages of social media platforms. These platforms have advantages such as volunteering, aid, charity organizations, performing and sharing art works, discussing ideas and projects with experts. Besides its advantages, social media platforms do create an addiction. The aim of the questionnaire-based survey study is to determine the social media addiction and its effect on mental health of the University students (20-28 years old) in Bangladesh. The study was designed as an online questionnaire survey which was distributed among the university students of Bangladesh via email and social media platform (Facebook). A total of 100 participants answered the questionnaire. The results of the survey found that the self-worth, self-esteem and overall mood of $93.2 \%$ of the students are affected if their shared social media contents are criticized. The result also indicated that $52.7 \%$ made unsuccessful attempts to cut back time from social media but failed and $47.3 \%$ did not attempt. An overall of $78.4 \%$ felt that they waste their time on social media platforms. $70.3 \%$ students indicated that they check their notifications on the social media apps whenever the notifications pop up. The major three responses from the study identified that the participants have severe social media dependence which is a leading factor to harming self-esteem and self-worth. Also, most spend their times on these platforms more than 60 hours per week which, by the definition of addiction, falls under the category. Thus, the study testified to the effect of social media addiction among university level students in Bangladesh.
\end{abstract}

Keywords: Social Media, Mental Health, Self-esteem, Self-worth, Bangladesh 
INTERNATIONAL JOURNAL OF ACADEMIC RESEARCH IN BUSINESS AND SOCIAL SCIENCES

Vol. 10, No. 4, April, 2020, E-ISSN: 2222-6990 @ 2020 HRMARS

\section{Introduction}

In the $21^{\text {st }}$ Century, the most practical and fastest way to reach information is undoubtedly the usage of social media platforms with the blessings of the internet technology (Tektaş, 2014; Kirik, 2015). The major difference of the virtual world from the real world is its temporary nature. Here the users can be of any virtual identity which makes the users remain highly active in these platforms (Alanka and Cezik, 2016).

Social Media Platforms have massive advantages such as volunteering, aid, charity organizations, performing and sharing art works, discussing ideas and projects with experts who are not easily accessible in real life. Social media plays an important role in the students' learning actions in the area of sustainable education today. The effect of social media is becoming an important and motivating force for sustainable education. The world is now a global village and technology usage has made it a smaller world through social media. There has recently been a debate on the adverse effects of the use of social media on people, especially young people and school groups worldwide.

During the last decade, the popularity of social media and social networking applications has increased steadily. Typically, adolescents and university students use social media apps to get global exposure to this rapid increase. These websites in social media like Facebook and Twitter are now the craze of our society for all. Today, students rely more and more on information and data that are easily accessible via social media and the internet. For this reason, student learning and research skills in certain situations decrease, as their involvement with these sites decreased their focus, resulting in less time spent on their studies and a decrease in academic performance (Abbas, 2019)

When students spend more time in social media, they spend less time socializing with others or in person. Students can also sometimes waste their time in social media. As a result, students cannot communicate and socialize effectively in individuals and strong communication skills are well known to play an important role in their performance.

The overuse of social media often impacts students' psychological and physical wellbeing. The students wait and refuse to rest properly, but drink tea or coffee too much to stay healthy and alert. The effect of this lifestyle on students' mental and physical health is negative. The daily overuse of social media is also unhealthy, since it prevents students from developing personal links. Families monitor their children's use of social media and should ensure their children use the Internet for a reasonable period. Finally, educators and colleagues can help students understand the negative impact of social media on their health and make them aware of what they can miss if they spend hours on real media websites (Abbas, 2019)

Such social networking sites have a negative impact that outweighs the positive. Such sites have therefore caused possible social damage. Students more often than anybody else become victims of social networks. This is due to social media being an attractive way for students to avoid boredom while they study or search online and to distract from their work (Abbas, 2019).

Social media platforms do create an addiction. The social media addiction of an individual can be described by some clinicians according to the concept of addiction. These are the failure to prevent overuse of social media, the need to spend more time on social media, the lack of time without connection with social media, the emergence of extreme nervousness, stress, anguish when deprived of work and social and family life (Bozkurt, 2016). According to addiction center, a typical social media addict uses social media platforms between 40-80 hours per week. Several emotional, relational, 
health and performance issues have been found to be linked to social media addiction as well (Marino, Gini, Vieno, \& Spada, 2018).

Social networking websites, including Facebook, Instagram and Twitter, have directly enabled the lives of people in the 21st century. But they have a different side, too. Social media addiction has now reached a level that has negative effects on the minds of all people obsessed with virtual life. Back on the scene, Bangla Tribune hosted a Boithoki roundtable on 12 October with representatives of different lifestyles and a psychologist and an anthropologist in his office in Dhaka, to find out how and why the addiction takes place. The program was moderated by journalist Munni Saha.

Abdullah Al Mamun, a program coordinator at Manusher Jonno Foundation, said: "People get a sort of mental satiation when they come across things that go with their mindset, which basically happens on social media. When it comes to issues of mutual interest, like politics, entertainment, or cooking, birds of a feather are flocking together, and developing the addiction."

He added: "The social media has made it very easy to find whatever we want and whenever we want based on our taste and preferences. People with similar tastes are forming groups on social media. These groups may have political bearings or may be based on entertainment. Some have even created groups on cooking. One is always viewing contents that match his or her preferences in these groups, creating addiction."

"We're living in an age where there are devices everywhere around us to create such addiction. Electronic devices and the social media are all set in such a way that one is easily getting the desired content without making much effort. So, capitalism also plays a role in this addiction."

Speaking at the roundtable, Bangla Tribune Editor Zulfikar Russell said: "Social media becomes an addiction when someone becomes dependent on it. A person going after their desired object repeatedly on social media is a form of addiction."

Zulfikar mentioned that, "we had originally used social media as a communication tool. We welcomed this because we used the forum to stay in touch with friends and relatives. But the utility trend has shifted. The more people like to receive their messages, the more they become involved in social media. Sharing some news reaches people quickly too."

He added, "but it has a negative side as well. Deliberate and inflammatory agenda or false news that spread on social media at the same rate when posted. Often social media users only see the misleading headlines of the news as false ideas without reading all the content (Dhaka Tribune, 2017)

Social media websites have been accused of behavioral problems such as anxiety, depression and attention deficiency. No exception is made to Bangladesh. Dhaka ranked second in terms of the number of active Facebook users according to the Q2 World Digital Statshot report in 2017 (The Daily Star, 2019).

A survey of university students has identified the prevalence of Facebook Addiction and its associations with several factors for risk and many results from Bangladesh agree with findings from research elsewhere. Examining multiple variables, the symptoms of de-pressure were found to be the most significant risk factors for the risk of Facebook Addiction.

Problematic Facebook use appears to have detrimental effects on mental health among a minority of individuals and is arguably becoming a public health problem because of the impact on physical health and psychological wellbeing among this minority. Previous studies outside of Bangladesh have reported associations between FA and depression (Błachnio, 2015; Pantic, 2012; Shensa, 2017; Wright, 2013), so the finding in the present Bangladeshi study supports that literature. 
INTERNATIONAL JOURNAL OF ACADEMIC RESEARCH IN BUSINESS AND SOCIAL SCIENCES Vol. 10, No. 4, April, 2020, E-ISSN: 2222-6990 @ 2020 HRMARS

In fact, depression independently and strongly correlates with many addictive behaviors including problematic social media use (Shensa, 2017).

The current study is conducted to determine the social media addiction and its effect on mental health among the Private University students of Bangladesh. It aims to fulfill the following objectives

- To determine the extent of social media dependence among the students by evaluating the frequency of checking social media notifications by the students.

- To determine the level of awareness of students about their dependence on social media platforms.

- To determine the overall social media addiction and its effect on mental health of the students.

\section{Literature Review}

Addiction to social media is one form of Internet addiction in which people are tempted to use social media incorrectly (Starcevic, 2013). People addicted to social media often always have an uncontrollable urge to communicate and use social media (Andreassen \& Pallesen, 2014).

Studies have shown that signs of social media dependency can occur in mood, memory, physical and emotional responses, interpersonal and psychological problems (Balakrishnan \& Shamim, 2013; Durak, \& Sherstyuk, 2017). At present, as all information are instantly available on social media platforms, it becomes very difficult to avoid negative information on social, economic, geographical and political issues which often effect the mental health of the students.

Several researches on social media use and mental health indicated that prolonged use of social media like Facebook is a contributing factor for mental health issues like stress, anxiety, depression and long-term well-being (Marino, 2017; Shakya \& Christakis, 2017; Toker \& Baturay, 2016).

A key difference between normal over-commitment to social media, which sometimes many people experience, and social media addiction is that this has adverse effects when social networking becomes uncontrollable and compulsive (Andreassen, 2015). Depression, anxiety, and insomnia are linked negatively to subjective well-being, subjective intensity and life-satisfaction (Bányai, 2017; Shensa, 2017; Schoenmakers, 2017; Hawi \& Samaha, 2017).

Many studies showed that low self-esteem is related to various psychological disorders, such as depression and fear (Sowislo \& Orth, 2013). Addiction towards social media may lead to lower selfesteem and, in effect, reduce mental health. Self-esteem, in other words, may play a mediating role in social media addiction on mental health. Most of the time it happens that, individuals start comparing their lives with another individual's virtual presence, achievements and appearances of life on social media platforms such as, Facebook and Instagram. Recently, it has also been discussed globally that the removal of the "like" option from Instagram may prevent attention seeking behavior, low self-esteem, low self-worth, insecurity, personality disorder, narcissism and depression.

Recent researches have looked at social networking services, personal and subject-based blogs, and internet forums put together to study the User and Gratification Theory in posting social content, the relationship between gratifications and narcissism, and the effects of age on this relationship and these gratifications. Users have motivations of the following overall: Social and affection, need to vent negative feelings, Recognition, Entertainment and Cognitive needs. 
INTERNATIONAL JOURNAL OF ACADEMIC RESEARCH IN BUSINESS AND SOCIAL SCIENCES

Vol. 10, No. 4, April, 2020, E-ISSN: 2222-6990 @ 2020 HRMARS

Therefore, it is of utmost importance to understand the extent of social media addiction prevalent among the university level students. The study explored the addiction of social media of the University Students of Bangladesh on mental health.

\section{Research Methodology}

The study was designed as an online questionnaire survey which was distributed among the private university (East West University) students of Bangladesh via email and social media platform (Facebook). A total of 100 participants answered the questionnaire. The questions (No, $1,2,4,5$, and 7) were adopted from (MACIT, 2018) with minor modifications and the rest of the questions were incorporated after consulting with respective experts. The data was collected in the month of December 2019. The study was conducted by the quantitative method using selfadministered questionnaire, descriptive analysis and the social media addiction of the University Students of Bangladesh were interpreted based on the result of the study and in the support of the studies that are previously executed.

\section{Result and Discussion}

\section{Age}

The survey responses were taken from university students between the range from 20-28 years old. Among the 100 responses, 55.5\% were in the range between 20-24 years old and $44.6 \%$ were in the range between $25-28$ years old (Figure 1 ).

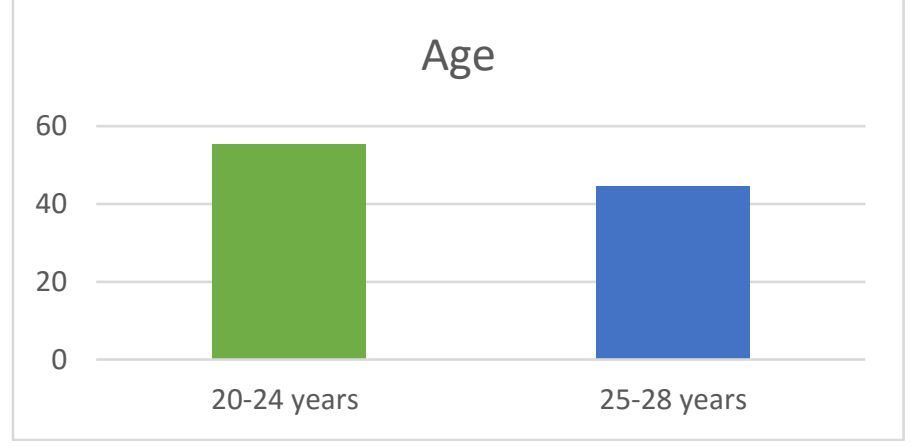

Figure 1: Age

The educational level of the participants was measured with a 2-choice question. Undergraduate and postgraduate options were presented to the participants. It was observed that $82.4 \%$ are undergraduate students and the rest $17.6 \%$ are postgraduate students from various universities of Bangladesh (Figure 2).

\section{Education}

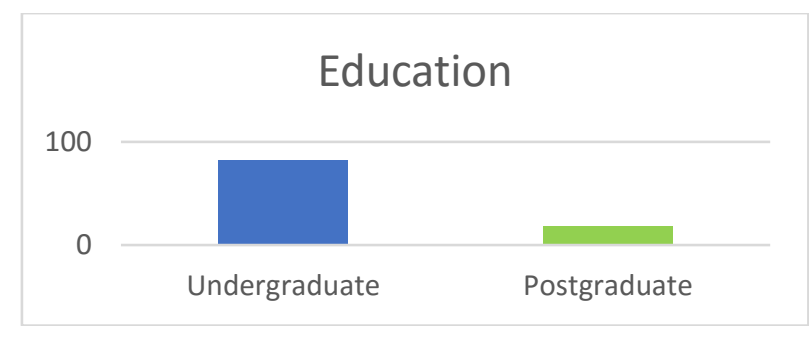

Figure 2: Education 
INTERNATIONAL JOURNAL OF ACADEMIC RESEARCH IN BUSINESS AND SOCIAL SCIENCES Vol. 10, No. 4, April, 2020, E-ISSN: 2222-6990 @ 2020 HRMARS

\section{Social Media Usage}

Participants answered the question about which social media platforms they use. In response to this question, from 100 University Students, it was obtained that, $87.8 \%$ use Facebook, $8.1 \%$ use Instagram, and $4.1 \%$ use both the platforms (Figure 3). And as the response on the time spent on these platforms, $8.1 \%$ responded that they spend 5-20 hours weekly on social media, $33.8 \%$ responded that they spend around $21-40$ hours weekly on these platforms, $16.2 \%$ spend $41-60$ hours weekly and the rest $41.9 \%$ spend more than 60 hours weekly (Figure 4).

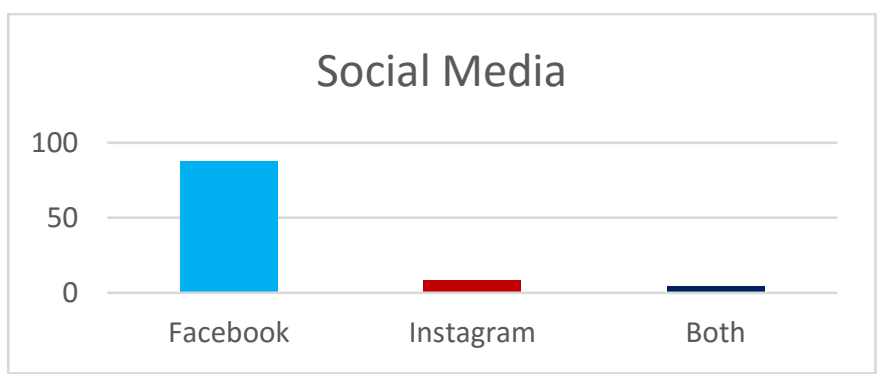

Figure 3: Social media usage

Hours spend in Social media weekly

Hours spend in Social media weekly

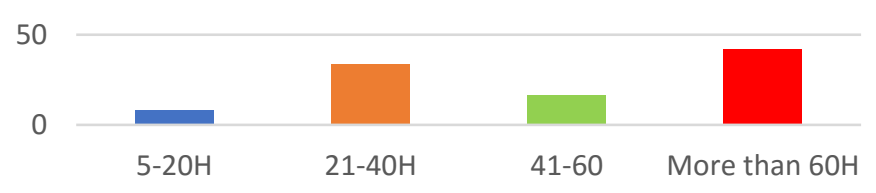

Figure 4: Hours spend in Social media weekly

Time wasted on Social Media Platforms

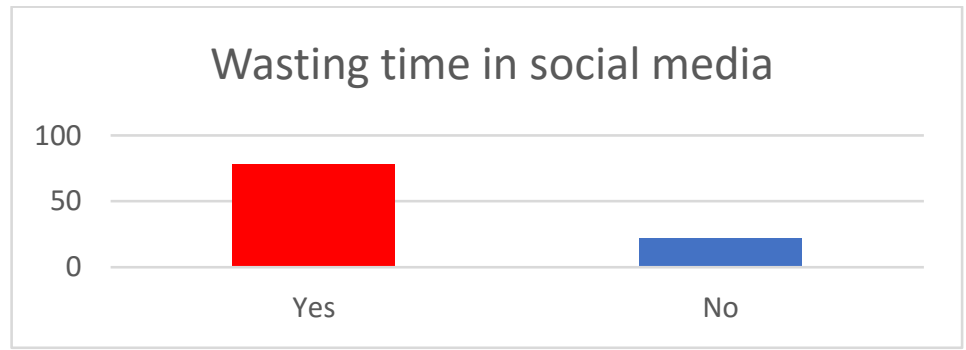

Figure 5: Time wasted on Social Media Platforms

According to the staked column (Figure 5), 78.4\% university students have answered "yes" that they waste their times on social media platforms and the rest $21.6 \%$ have stated that they do not particularly waste their times on these platforms. It is an indication about how severely the university students are wasting their times on virtual and unrealistic platforms. 
INTERNATIONAL JOURNAL OF ACADEMIC RESEARCH IN BUSINESS AND SOCIAL SCIENCES

Vol. 10, No. 4, April, 2020, E-ISSN: 2222-6990 @ 2020 HRMARS

\section{Attempts of Cutting Back on Social Media Usage}

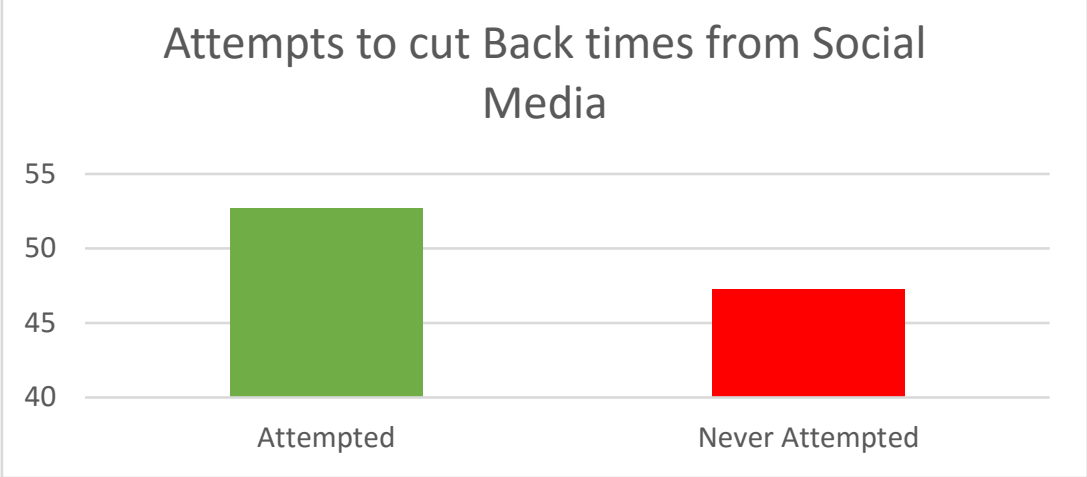

Figure 6: Attempts of Cutting Back on Social Media Usage

According to the staked column (Figure 6), 52.7\% university students have made attempts to cut back their times from using social media platforms but have been unsuccessful. The rest $47.3 \%$ have not even tried to stop using social media platforms. It is alarming because it indirectly indicated the students' unhealthy dependence on social media platforms.

The addiction level of addicts to smoking has been measured by checking that they smoke before they sleep at night and after they get up in the morning. Several studies have shown the same signs of Internet addiction as cigarettes, alcohol and drug dependency. Based on these data, the participants in this study were asked three important questions to identify the students' awareness about social media addiction.

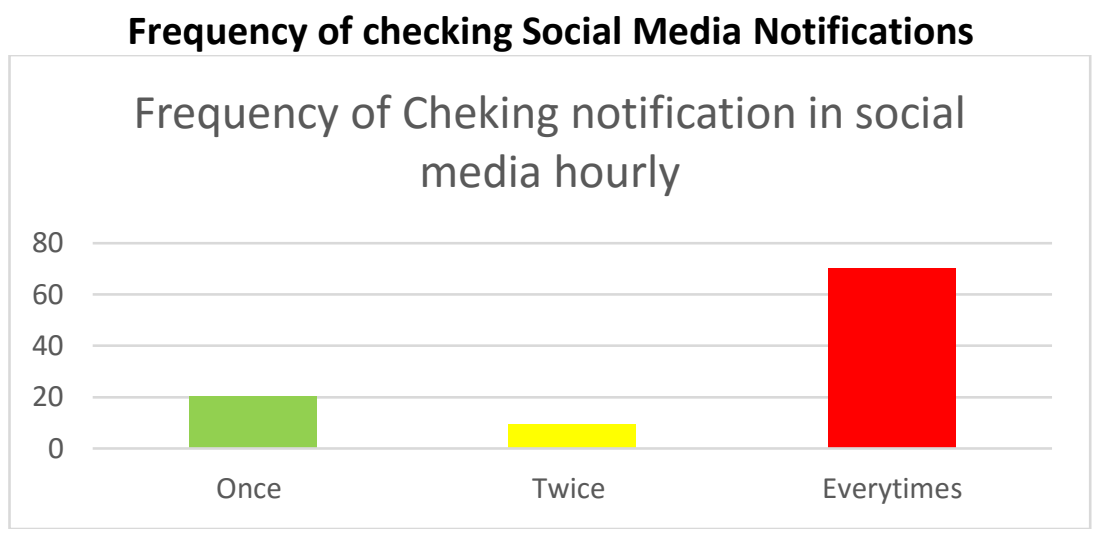

Figure 7: Frequency of checking Social Media Notifications

According to the staked column (Figure 7), 20.3\% university students check their social media notifications once every hour and $9.5 \%$ of university students check their social media notifications twice every hour in their day to day lives. It also showed that, $70.3 \%$ university students check their social media notifications whenever it notifies on their devices. This is an indication of the dependence the university level students have on social media platforms. 
INTERNATIONAL JOURNAL OF ACADEMIC RESEARCH IN BUSINESS AND SOCIAL SCIENCES Vol. 10, No. 4, April, 2020, E-ISSN: 2222-6990 @ 2020 HRMARS

\section{Social Media Effect}

The second question asked to the participants were, if the social media comments, feedbacks and criticisms affect their self-worth and self-esteem, to that, $93.2 \%$ responded affirmatively and the remaining $6.8 \%$ responded that the social media criticisms and feedbacks do not necessarily affect them in their daily lives and do not affect their mental health or personal growth (Figure 8).

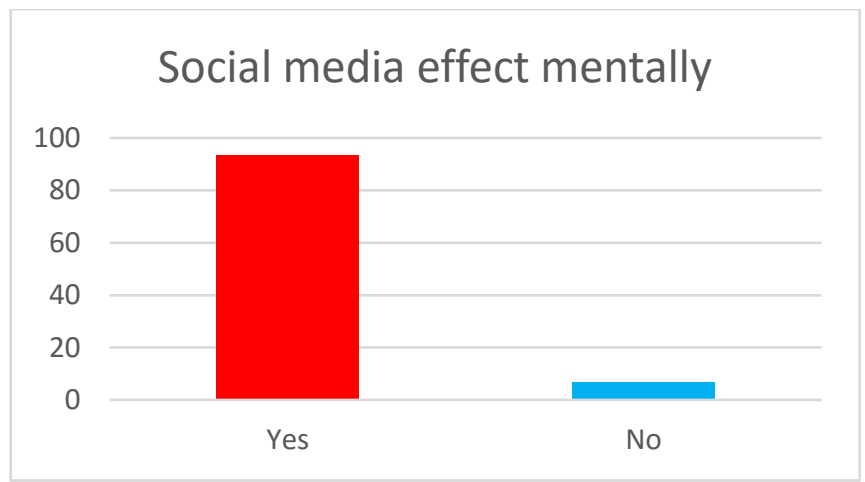

Figure 8: Social media effect mentally

\section{Level of awareness about addiction on social media}

The last question asked to the participants were about their awareness regarding their social media addiction. Figure 8 showed, $72.2 \%$ answered affirmatively indicating that they are clearly aware of their social media dependence which may potentially fall into addiction. Among 100 respondents, $18 \%$ responded that they were unsure about their status of social media addiction and the rest of the $9.8 \%$ denied that they have any sort of awareness about addiction to social media platforms.

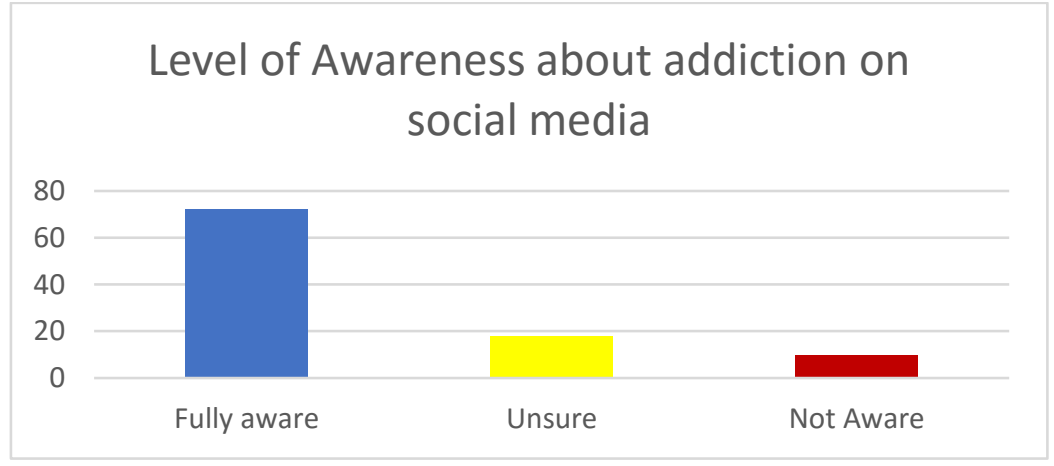

Figure 9: Level of awareness about addiction on social media

In this study, participants were conscious of their addiction to social media with their patterns of using social media. The degree of addiction in social media users is higher and in audience-only users, the degree of addiction is lower. The association between the use to social media and the level of education and age is not important. Through social media, the average time spent on a day is clearly higher among addicts. 
The additional responses were recorded as well, where they were asked if they stay online on these platforms more than they intend to. It was observed that, only $18.1 \%$ do not stay on these platforms more than they need to which revealed that, $81.1 \%$ of participants often spend their times on social media platforms more than they require to. And most times, the reasons behind persistently staying online on these platforms are simply scrolling down to see other peoples' updates, world news, online entertainments such as, trolls and memes.

The above study is a clear indicator to the possibility of social media addiction among the university level students in Bangladesh. The major three responses from the study identified that the participants have severe social media dependence which is a leading factor to harming selfesteem and self-worth. It is also observed that, majority participants spend their times on these platforms more than 60 hours per week which, by the definition of addiction, falls under the category of social media addiction.

According to the Hyper personal Model, self-esteem is one of the reasons behind the negative effects of social media use. Although viewing or editing the own online profile enhances self-esteem, social media users frequently face selective and glorified online presentations of others, which can reduce the self-esteem of viewers (Rosenberg \& Egbert, 2011). Many Facebook users assume, for instance, that others are happier and more successful, especially when they do not know others offline (Chou \& Edge, 2012). The fact is, there is no truth to the conclusion that other people on these platforms are more successful or happier in their lives. It is just a virtual illusion which consumes everyone irrespective of age and gender. It gives the users and empty feeling and dissatisfaction which only result in insecurity, low self-esteem, unhappiness and ultimately, depression.

\section{Recommendation and Conclusion}

In conclusion, it can be indicated that there is a positive relationship between social media addiction and the mental health of the university students of Bangladesh. The result of the study can be beneficial for the respective policy makers of the country to take proper measurements in dealing with social media addiction cases. The government stakeholders, University council centers, and mental health organizations can use this study as their references in identifying the social media addiction and undertaking preventive or remedial actions to help and guide the young university students. Moreover, the prevalence of a study like this is scarce in the context of Bangladesh, hence, making the study an utmost importance for taking better approaches in balancing the mental health of the students of the country. However, more empirical studies are required to have a constructive conclusion on this topic. Recommendations include, a young individual must be self-aware of the fact that these platforms and entirely virtual and superficial and only a certain amount of time on these platforms are more than enough to be an active user. Public and private educational institutions should also step up in considering the extensive use of social media as an indicator of various mental health issues such as, anxiety, depression, stress and panic. It can help both the parties help one another in reducing the extensive usage of social media and affecting the mental health of the youth of Bangladesh.

Acknowledgement: The authors would like to thank each contributor for support. Finally, authors acknowledge the proofreading and editing support of Onism Consultancy. 
INTERNATIONAL JOURNAL OF ACADEMIC RESEARCH IN BUSINESS AND SOCIAL SCIENCES Vol. 10, No. 4, April, 2020, E-ISSN: 2222-6990 @ 2020 HRMARS

\section{Corresponding Author}

Name: Tahiya Islam

Institution: Department of Biomedical Sciences, Faculty of Medicine and Health Sciences, Universiti Putra Malaysia, Serdang, 43400 Seri Kembangan, Selangor

Email: tahiya945@gmail.com

\section{References}

Abbas, J., Aman, J., Nurunnabi, M., \& Bano, S. (2019). The impact of social media on learning behavior for sustainable education: evidence of students from selected universities in Pakistan. Sustainability, 11(6), 1683.

Alanka, Ö., Cezik, A. (2016), Dijital Kibir: Sosyal Medyadaki Narsistik Ritüellere İlişkin Bir İnceleme, TRT Akademi, (1)2-Dijital Medya Sayısı, 548-570, ISSN: 2149-9446.

Andreassen, C. S. (2015). Online social network site addiction: A comprehensive review. Current Addiction Reports, 2, 175-184. https://doi.org/10.1007/s40429-015-0056-9

Andreassen, C. S., \& Pallesen, S. (2014). Social network site addiction-an overview. Current Pharmaceutical Design, 20, 4053-4061. https://doi.org/10.2174/13816128113199990616

Andreassen, C. S., Pallesen, S., \& Griffiths, M. D. (2017). The relationship between addictive use of social media, narcissism, and self-esteem: Findings from a large national survey. Addictive Behaviors, 64, 287-293. https://doi.org/10.1016/j.addbeh.2016.03.006

Andreassen, C. S., Torsheim, T., Brunborg, G. S., \& Pallesen, S. (2012). Development of a Facebook addiction scale. Psychological Reports, 110, 501-517. https://doi.org/10.2466/02.09.18.PR0.110.2.501-517

Bányai, F., Zsila, Á., Király, O., Maraz, A., Elekes, Z., Griffiths, M. D., . . . Demetrovics, Z. (2017). Problematic social media use: Results from a large-scale nationally representative adolescent sample. PLoS One, 12, e0169839. https://doi.org/10.1371/journal.pone.0169839

Błachnio, A., Przepiórka, A., \& Pantic, I. (2015). Internet use, Facebook intrusion, and depression: Results of a cross-sectional study. European Psychiatry, 30(6), 681-684.

Błachnio, A., Przepiorka, A., \& Pantic, I. (2016). Association between Facebook addiction, self-esteem and life satisfaction: A cross-sectional study. Computers in Human Behavior, 55, 701-705. https://doi.org/10.1016/j.chb.2015.10.026

Bozkurt, H., Şahin, S., Zoroğlu, S. (2016), İnternet Bağımlılığı: Güncel Bir Gözden Geçirme, Journal of Contemporary Medicine,6(3): 235-247, DOI: 10.16899/ctd.66303

Caplan, S. E. (2010). Theory and measurement of generalized problematic Internet use: A two-step approach. Computers in Human Behavior, 26, 1089-1097. https://doi.org/10.1016/j.chb.2010 .03 .012

Casale, S., Rugai, L., \& Fioravanti, G. (2018). Exploring the role of positive metacognitions in explaining the association between the fear of missing out and social media addiction. Addictive Behaviors, 85, 83-87. https://doi.org/10.1016/j.addbeh.2018.05.020

Chou, H. T. G., \& Edge, N. (2012). "They are happier and having better lives than I am": The impact of using Facebook on perceptions of others' lives. Cyberpsychology, Behavior, and Social Networking, 15, 117-121. https://doi.org/10.1089/cyber.2011.0324

Griffiths, M. D. (2012). Facebook addiction: Concerns, criticism, and recommendations: A response to Andreassen and colleagues. Psychological Reports, 110, 518-520. 
INTERNATIONAL JOURNAL OF ACADEMIC RESEARCH IN BUSINESS AND SOCIAL SCIENCES

Vol. 10, No. 4, April, 2020, E-ISSN: 2222-6990 @ 2020 HRMARS

https://doi.org/10.2466/01.07.18.PR0.110.2.518-520

Hawi, N. S., \& Samaha, M. (2017). The relations among social media addiction, self-esteem, and life satisfaction in university students. Social Science Computer Review, 35, 576-586. https://doi.org/10.1177/0894439316660340

Macit, H. B., Macit, G., \& Güngör, O. (2018). A Research on Social Media Addiction and Dopamine Driven Feedback. Mehmet Akif Ersoy Üniversitesi Iktisadi ve Idari Bilimler Fakültesi Dergisi, 5(3), 882-897.

Jelenchick, L. A., Eickhoff, J. C., \& Moreno, M. A. (2013). “Facebook depression?” Social networking site use and depression in older adolescents. Journal of Adolescent Health, 52, 128-130. https://doi.org/10.1016/j.jadohealth.2012.05.008

Junco, R. (2012). The relationship between frequency of Facebook use, participation in Facebook activities, and student engagement. Computers \& Education, 58, 162-171. https://doi.org/10.1016/j.compedu.2011.08.004

Kırık, A. M., Arslan, A., Çetinkaya, A., Gül, M. (2015). A Quantitative Research on the Level of Social Media Addiction among Young People in Turkey, International Journal of Science Culture and Sport, 3(3), 108-122

Lin, C. Y., Broström, A., Nilsen, P., Griffiths, M. D., \& Pakpour, A. H. (2017). Psychometric validation of the Persian Bergen Social Media Addiction Scale using classic test theory and Rasch models. Journal of Behavioral Addictions, 6, 620-629. https://doi.org/10.1556/2006.6.2017.071

Malik, S., \& Khan, M. (2015). Impact of Facebook addiction on narcissistic behavior and self-esteem among students. Journal of Pakistan Medical Association, 65, 260-263.

Marino, C., Finos, L., Vieno, A., Lenzi, M., \& Spada, M. M. (2017). Objective Facebook behaviour: Differences between problematic and non-problematic users. Computers in Human Behavior, 73, 541-546. https://doi.org/10.1016/j.chb.2017.04.015

Marino, C., Gini, G., Vieno, A., \& Spada, M. M. (2018). A comprehensive meta-analysis on problematic Facebook use. Computers in Human Behavior, 83, 262-277. https://doi.org/10.1016 /j.chb.2018.02.009

Mehdizadeh, S. (2010). Self-presentation 2.0: Narcissism and self-esteem on Facebook. Cyberpsychology, Behavior, and Social Networking, 13, 357-364. https://doi.org/10.1089 /cyber.2009.0257

Monacis, L., De Palo, V., Griffiths, M. D., \& Sinatra, M. (2017). Social networking addiction, attachment style, and validation of the Italian version of the Bergen Social Media Addiction Scale. Journal of Behavioral Addictions, 6, 178-186. https://doi.org/10.1556 /2006.6.2017.023

Orth, U., \& Robins, R. W. (2013). Understanding the link between low self-esteem and depression. Current Directions in Psychological Science, 22, 455-460. https://doi.org/10.1177 /0963721413492763

Oulasvirta, A., \& Saariluoma, P. (2006). Surviving task interruptions: Investigating the implications of long-term working memory theory. International Journal of Human-Computer Studies, 64, 941-961. https://doi.org/10.1016/j.ijhcs.2006.04.006

Pantic, I. (2014). Online social networking and mental health. Cyberpsychology, Behavior, and Social Networking, 17, 652-657. https://doi.org/10.1089/cyber.2014.0070 
INTERNATIONAL JOURNAL OF ACADEMIC RESEARCH IN BUSINESS AND SOCIAL SCIENCES Vol. 10, No. 4, April, 2020, E-ISSN: 2222-6990 @ 2020 HRMARS

Rosenberg, J., \& Egbert, N. (2011). Online impression management: Personality traits and concerns for secondary goals as predictors of self-presentation tactics on Facebook. Journal of Computer-Mediated Communication, 17(1), 1-18.

Shakya, H. B., \& Christakis, N. A. (2017). Association of Facebook use with compromised well-being: A longitudinal study. American Journal of Epidemiology, 185, 203-211. https://doi.org/10.1093/aje/kww189

Shensa, A., Escobar-Viera, C. G., Sidani, J. E., Bowman, N. D., Marshal, M. P., \& Primack, B. A. (2017). Problematic social media use and depressive symptoms among US young adults: A nationallyrepresentative study. Social Science \& Medicine, 182, 150-157.

https://doi.org/10.1016/j.socscimed.2017.03.061

Smith, A., \& Anderson, M. (2018). Social media use in 2018. Retrieved from http://www.pewinternet.org/2018/03/01/social-media-use-in-2018/

Sowislo, J. F., \& Orth, U. (2013). Does low self-esteem predict depression and anxiety? A metaanalysis of longitudinal studies. Psychological Bulletin, 139, 213-240. https://doi.org/10.1037/a0028931

Starcevic, V. (2013). Is Internet addiction a useful concept? Australian and New Zealand Journal of Psychiatry, 47, 16-19. https://doi.org/10.1177/0004867412461693

Stone, C. B., \& Wang, Q. (2018). From conversations to digital communication: The mnemonic consequences of consuming and sharing information via social media. Topics in Cognitive Science, 2018, 1-20. https://doi.org/10.1111/tops.12369

Tang, J. H., Chen, M. C., Yang, C. Y., Chung, T. Y., \& Lee, Y. A. (2016). Personality traits, interpersonal relationships, online social support, and Facebook addiction. Telematics and Informatics, 33, 102-108. https://doi.org/10.1016/j.tele.2015.06.003

Tektaş, N. (2014). Üniversite Öğrencilerinin Sosyal Ağları Kullanımlarına Yönelik Bir Araştırma, Journal of History School, (7)17, 851-870, DOI: 10.14225/Joh474

Leung, L. (2013). "Generational Differences in Content Generation in Social Media: The Roles of the Gratifications Sought and of Narcissism". Computers in Human Behavior. 29 (3): 997-1006. doi:10.1016/j.chb.2012.12.028.

Vogel, E. A., Rose, J. P., Roberts, L. R., \& Eckles, K. (2014). Social comparison, social media, and selfesteem. Psychology of Popular Media Culture, 3, 206-222. https://doi.org/10.1037/ppm0000047

Young, K. S. (1999). Internet addiction: Symptoms, evaluation and treatment. In L. VandeCreek \& T. L. Jackson (Eds.), Innovations in clinical practice: A source book (Vol 17, pp. 19-31). Sarasota, FL: Professional Resource Press.

Young, K. S. (2007). Cognitive behavior therapy with Internet addicts: Treatment outcomes and implications. CyberPsychology \& Behavior, 10, 671-679. https://doi.org/10.1089/cpb.2007.9971

Zaremohzzabieh, Z., Samah, B. A., Omar, S. Z., Bolong, J., \& Kamarudin, N. A. (2014). Addictive Facebook use among university students. Asian Social Science, 10, 107. https://doi.org/10.5539/ass.v10n6p107

Zywica, J., \& Danowski, J. (2008). The faces of Facebookers: Investigating social enhancement and social compensation hypotheses: Predicting Facebook ${ }^{\mathrm{TM}}$ and offline popularity from sociability 
INTERNATIONAL JOURNAL OF ACADEMIC RESEARCH IN BUSINESS AND SOCIAL SCIENCES

Vol. 10, No. 4, April, 2020, E-ISSN: 2222-6990 @ 2020 HRMARS

and self-esteem and mapping the meanings of popularity with semantic networks. Journal of Computer-Mediated Communication, 14, 1-34. https://doi.org/10.1111/j.1083-

6101.2008.01429.x 